\title{
Research on the Relationship between Business Administration Majors' Training Modes and Employability
}

\author{
Xing $\mathrm{Li}^{1}$, Sheng Zhao ${ }^{2}$, Jianmin $\mathrm{He}^{1}$ \\ \{XXXX@Springer.com\} \\ 1College of Economy and Management,LongDong University ,QingYang City,Gansu \\ 2Project finance department,LongDong University, QingYang City,Gansu
}

\begin{abstract}
With the use of questionnaire surveys and interviews, this research conducted exploratory factor analysis and confirmatory factor analysis with software SPSS20.0 on the sample data recovered, and then built a structural model on Chinese business administration majors' employability. The research drew the following conclusion: the structural model on business administration majors' employability involves five factors: basic skills, specialized competence, ability to outreach, career development and management capabilities; the structural model on business administration personnel training modes involves six factors: teachers' teaching skills and attitudes, curriculum, practical training, construction of campus culture, training evaluation and job search guidance. The six components of business administration personnel training modes and students' willingness to learn are significantly positively correlated.
\end{abstract}

Keywords: personnel training, employability, structural model, empirical study

\section{Introduction}

This research is designed to explore the structural model on the employability of Chinese business administration majors, thereby laying the foundation for the research of the relationship between personnel training modes and students' employability [1]. First, on the basis of relevant domestic and foreign studies on employability, the research through interviews and open-ended questionnaire surveys obtained the component items of employability for business administration majors and initially developed a scale on business administration majors' employability. By a pre-test of the scale based on a certain number of samples, the items of the scale were initially analyzed to delete items that do not meet the requirements and to test the reliability and validity of the scale, thus formed the formal scale [2]. Later, with the use of SPSS20.0 the survey data collected was put under exploratory factor analysis to build the structural model on business administration majors' employability, and then with the use of confirmatory factor analysis the degree of fitting of the model was tested, thereby forming the conceptual model on business administration majors' employability (Fig. $1)$. 


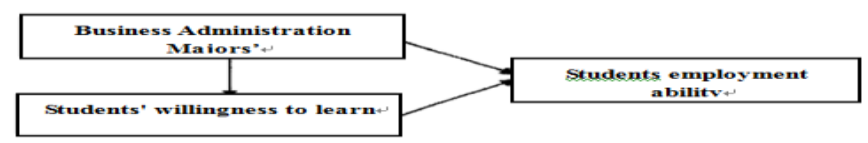

Fig.1. Tionship between business administration majors' training modes and employability conceptual model

The following hypotheses were proposed.

H1: Business administration personnel training modes and students' willingness to learn are positively correlated.

H2: Business administration personnel training modes and students' willingness to learn combined affect students' employability; the various dimensions of personnel training modes and students' willingness to learn have different predictive effects on the various dimensions of students' employability [3].

\section{Research Methods}

This research used two methods of field survey and online survey. The field survey selected business administration undergraduates from Asia University Taiwan, Lanzhou University of Finance and Economics, Xidian University [4], Sun Yat-sen University School of Management, and Xi'an Jiaotong University. In online survey, the samples were dispersedly distributed, involving different majors from a number of schools. The field and online surveys recovered a total of 269 copies of questionnaire. Excluding the unanswered, the data was clearly not in conformity with the requirements (e.g. selecting the same option for all questions). There were also 55 copies answered by majors other than Business Administration. So, there were a total of 214 valid copies, i.e. the recovery rate of $79.6 \%[5,6]$. To test whether the scale is suitable for factor analysis, the research first used software SPSS20.0 to conduct a sampling adequacy test of the 214 samples in the scale, where KMO test and Bartlett test of sphericity were used. As Table 1 shows, the sampling adequacy (KMO) value was 0.956 , very close to 1 , indicating that the relationship between the questions was excellent; in Bartlett's test the chi-square value was 4764.856, degree of freedom coefficient 406, significance coefficient less than 0.000 , very significant, indicating an excellent sampling adequacy of the data, very suitable for factor analysis. Test results showed that the data sampled was suitable for factor analysis [7].

Table 1. Business administration professional training model satisfaction scale sampling relevance analysis

\begin{tabular}{|c|c|c|}
\hline \multicolumn{2}{|c|}{ KMO sample adequacy measure } & 0.956 \\
\hline \multirow{3}{*}{ Bartlett's test } & Chi square value & 4764.856 \\
\cline { 2 - 3 } & freedom & 406 \\
\cline { 2 - 3 } & Significant coefficient & 0.000 \\
\hline
\end{tabular}


After that, the 24 questions in the Satisfaction Scale were put under factor analysis, where the principal component analysis was used to extract the common factors. Using orthogonal rotation as the rotation method and eigenvalue greater than 1 as the standard, six factors were extracted, which cumulatively explained $61.641 \%$ of the total variance in the data. shows that the factor structure of library science personnel training modes was relatively clear, and questions contained in each factor were substantially the same, indicating that the questions distribution was more reasonable.

After the exploratory data analysis of the formal scale, the structural model on business administration personnel training modes was obtained. In order to verify the degree of fitting of the model and determine its reasonableness, the research continued to conduct the confirmatory analysis of the model using software AMOS20.0, where the indicators and criterion used were the same with the exploratory data analysis. The values of various indicators in Table 2 show that the 2odel's various fitting indicators reached the conditions of goodness of fitting, showing that the structural model on business administration personnel training modes had a good degree of fitting

Table 2. Fitting index confirmatory factor analysis

\begin{tabular}{|l|l|l|l|l|l|l|l|}
\hline$X^{2}$ & $d f$ & $\mathrm{X}^{2} / d f$ & $N F I$ & NNFI & IFI & CFI & RMSEA \\
\hline 348.9 & 125 & 2.791 & 0.95 & 0.95 & 0.92 & 0.92 & 0.069 \\
\hline
\end{tabular}

The values of the various indicators in Table 2 show that the various fit indicators of library science personnel training modes were all up to standard, indicating that the degree of fitting of the model was very good and acceptable.

In this part the research only tested the internal consistency of the scale. Table 3 shows the internal consistency coefficients of the total scale and six factors extracted after exploratory factor analysis was done on the scale, wherein the scale's total reliability coefficient was 0.870 , indicating that the reliability was very good; the consistency coefficients of the other five factors were $0.853,0.812,0.803,0.766,0.748$, and 0.743 , respectively, all greater than 0.7 , indicating that the reliability was also ideal.

Table 3. Business management training mode satisfaction scale letter scale

\begin{tabular}{|c|c|c|c|c|c|c|c|}
\hline & Gross list & Factor 1 & Factor 2 & Factor 3 & Factor 4 & Factor 5 & Factor 6 \\
\hline Crombacha & 0.870 & 0.853 & 0.812 & 0.803 & 0.766 & 0.748 & 0.743 \\
\hline Item number & 24 & 4 & 4 & 4 & 4 & 5 & 3 \\
\hline
\end{tabular}

The research in part tested the structural model on business administration personnel training modes mainly with the use of construct validity. A construct validity test commonly uses factor analysis. After exploratory factor analysis, the structural model on business administration personnel training modes included six factors, in which the load factor was greater than 0.50 and the cumulative variance contribution rate of common factors reached $61.641 \%$, while the load value of each item on the corresponding common factor was greater than 0.4 and that was lower on other common factors, so the scale had a good construct validity. 


\section{Results}

Using SPSS20.0, a correlation analysis was conducted on the variables in the structural model on personnel training modes and the structural mode on students' employability. The results are shown in Table 4.

Table 4. The relative analyzing results of business administration talents training mode and students' employment ability

\begin{tabular}{|c|c|c|c|c|c|c|c|c|c|c|c|c|}
\hline & 1 & 2 & 3 & 4 & 5 & 6 & 7 & 8 & 9 & 10 & 11 & 12 \\
\hline $\begin{array}{c}\text { Teachers' } \\
\text { teaching ability } \\
\text { and attitude }\end{array}$ & 1 & & & & & & & & & & & \\
\hline $\begin{array}{l}\text { Curriculum } \\
\text { setting }\end{array}$ & $\begin{array}{l}0.4 \\
98 * \\
*\end{array}$ & 1 & & & & $\begin{array}{l}\text { var } \\
\text { iabl } \\
\mathrm{e}\end{array}$ & & & & & & \\
\hline $\begin{array}{l}\text { Practice } \\
\text { training }\end{array}$ & $\begin{array}{l}0.3 \\
68 * \\
*\end{array}$ & $\begin{array}{l}0.5 \\
44^{*} \\
*\end{array}$ & 1 & & & & & & & & & \\
\hline $\begin{array}{l}\text { construction of } \\
\text { campus culture }\end{array}$ & $\begin{array}{l}0.3 \\
31 * \\
*\end{array}$ & $\begin{array}{l}0.4 \\
26^{*} \\
*\end{array}$ & $\begin{array}{l}0.5 \\
61 * \\
*\end{array}$ & 1 & & & & & & & & \\
\hline $\begin{array}{c}\text { Training } \\
\text { evaluation }\end{array}$ & $\begin{array}{l}0.4 \\
26^{*} \\
*\end{array}$ & $\begin{array}{l}0.5 \\
87 * \\
*\end{array}$ & $\begin{array}{l}0.4 \\
62 * \\
*\end{array}$ & $\begin{array}{l}0.3 \\
53 * \\
*\end{array}$ & 1 & & & & & & & \\
\hline $\begin{array}{l}\text { Job hunting } \\
\text { Guidance }\end{array}$ & $\begin{array}{l}0.3 \\
23 * \\
*\end{array}$ & $\begin{array}{l}0.2 \\
85^{*} \\
*\end{array}$ & $\begin{array}{l}0.2 \\
23^{*} \\
*\end{array}$ & $\begin{array}{l}0.3 \\
22 * \\
*\end{array}$ & $\begin{array}{l}0.1 \\
95^{*} \\
*\end{array}$ & 1 & & & & & & \\
\hline Basic ability & $\begin{array}{l}0.1 \\
01 * \\
*\end{array}$ & $\begin{array}{l}0.1 \\
21\end{array}$ & $\begin{array}{l}0.3 \\
73^{*} \\
*\end{array}$ & $\begin{array}{l}0.2 \\
11^{*}\end{array}$ & $\begin{array}{l}0.1 \\
93 *\end{array}$ & $\begin{array}{l}0.0 \\
95\end{array}$ & 1 & & & & & \\
\hline $\begin{array}{l}\text { Professional } \\
\text { competence }\end{array}$ & $\begin{array}{l}0.1 \\
97 * \\
*\end{array}$ & $\begin{array}{l}0.2 \\
99 * \\
*\end{array}$ & $\begin{array}{l}0.2 \\
23^{*}\end{array}$ & $\begin{array}{l}0.1 \\
03\end{array}$ & $\begin{array}{l}0.2 \\
78^{*} \\
*\end{array}$ & $\begin{array}{l}0.0 \\
85\end{array}$ & $\begin{array}{l}0.3 \\
11 * \\
*\end{array}$ & 1 & & & & \\
\hline $\begin{array}{l}\text { Ability to } \\
\text { expand }\end{array}$ & $\begin{array}{l}0.2 \\
33 *\end{array}$ & $\begin{array}{l}0.1 \\
45^{*}\end{array}$ & $\begin{array}{l}0.1 \\
76^{*}\end{array}$ & $\begin{array}{l}0.3 \\
35^{*} \\
*\end{array}$ & $\begin{array}{l}0.2 \\
05^{*}\end{array}$ & $\begin{array}{l}0.2 \\
49 * \\
*\end{array}$ & $\begin{array}{l}0.3 \\
27 * \\
*\end{array}$ & $\begin{array}{l}0.3 \\
49 * \\
*\end{array}$ & 1 & & & \\
\hline $\begin{array}{c}\text { Professional } \\
\text { development } \\
\text { ability }\end{array}$ & $\begin{array}{l}0.2 \\
86 * \\
*\end{array}$ & $\begin{array}{l}0.1 \\
57^{*}\end{array}$ & $\begin{array}{l}0.2 \\
35^{*} \\
*\end{array}$ & $\begin{array}{l}0.1 \\
95^{*}\end{array}$ & $\begin{array}{l}0.0 \\
91\end{array}$ & $\begin{array}{l}0.0 \\
97\end{array}$ & $\begin{array}{l}0.4 \\
94 * \\
* \\
\end{array}$ & $\begin{array}{l}0.2 \\
76^{*} \\
* \\
\end{array}$ & $\begin{array}{l}0.5 \\
30 * \\
*\end{array}$ & 1 & & \\
\hline $\begin{array}{l}\text { Managementabi } \\
\text { lity }\end{array}$ & $\begin{array}{l}0.1 \\
93\end{array}$ & $\begin{array}{l}0.1 \\
91^{*}\end{array}$ & $\begin{array}{l}0.2 \\
86^{*} \\
*\end{array}$ & $\begin{array}{l}0.2 \\
72 * \\
*\end{array}$ & $\begin{array}{l}0.2 \\
09^{*}\end{array}$ & $\begin{array}{l}0.0 \\
85\end{array}$ & $\begin{array}{l}0.4 \\
32 * \\
*\end{array}$ & $\begin{array}{l}0.5 \\
41 * \\
*\end{array}$ & $\begin{array}{l}0.3 \\
35^{*} \\
*\end{array}$ & $\begin{array}{l}0.3 \\
14^{*} \\
*\end{array}$ & 1 & \\
\hline $\begin{array}{l}\text { Willingness to } \\
\text { learn }\end{array}$ & $\begin{array}{l}0.2 \\
76^{*} \\
*\end{array}$ & $\begin{array}{l}0.2 \\
85^{*} \\
*\end{array}$ & $\begin{array}{l}0.3 \\
34 * \\
*\end{array}$ & $\begin{array}{l}0.1 \\
31^{*} \\
*\end{array}$ & $\begin{array}{l}0.4 \\
24 * \\
*\end{array}$ & $\begin{array}{l}0.2 \\
04 *\end{array}$ & $\begin{array}{l}0.0 \\
89\end{array}$ & $\begin{array}{l}0.3 \\
45^{*} \\
*\end{array}$ & $\begin{array}{l}0.3 \\
13 * \\
*\end{array}$ & $\begin{array}{l}0.2 \\
43^{*} \\
*\end{array}$ & $\begin{array}{l}0.2 \\
21^{*} \\
*\end{array}$ & 1 \\
\hline
\end{tabular}




$$
* *: \mathrm{p}>0.01 \quad *: \mathrm{p}<0.05
$$

The six factors contained in the structural model on business administration personnel training modes, i.e. teachers' teaching skills and attitudes, practical training, training evaluation, curriculum, campus culture construction and job search guidance, together with the students' willingness to learn were regarded as predictive variables. The outcome variables were the five factors contained in the structural model on business administration majors' employability, namely students' basic skills, specialized competence, ability to outreach, career development and management capabilities.

Table 5. Roadmap fit index

\begin{tabular}{|c|l|l|l|l|l|l|l|}
\hline$X^{2}$ & $D F$ & $X^{2} / d f$ & $N F I$ & $N N F I$ & $I F I$ & $C F I$ & $R M S E A$ \\
\hline 51.926 & 12 & 2.327 & 0.96 & 0.95 & 0.97 & 0.92 & 0.0849 \\
\hline
\end{tabular}

All indicators reached the measurement standard, indicating that the degree of fitting of the model was good and acceptable. The results of the road map showed that teachers' teaching skills and attitudes had a directly positive predictive effect on both students' basic skills and ability of career development; curriculum had a directly positive predictive effect only on students' specialized competence; practical training had a directly positive predictive effect on students' basic skills, career development and management capabilities; campus culture construction had a directly positive predictive effect only on students' management skills; training evaluation had a directly positive predictive effect only on students' ability to outreach; job search guidance had a directly positive predictive effect only on students' ability to outreach; willingness to learn had a directly positive predictive effect only on students' specialized competence. In summary, the research validated H2, namely that business administration personnel training modes and students' willingness to learn combined affected students' employability, and the various dimensions of personnel training modes and students' willingness to learn played different roles in predicting the various dimensions of students' employability.

\section{Conclusion}

In examining students' employability as a control variable, the research obtained from Table 5 the influence of the various dimensions of personnel training modes on students' willingness to learn. The results of analysis showed that teachers' teaching skills and attitudes, curriculum, practical training, construction of campus culture, training evaluation and willingness to learn were highly positively correlated and the correlation was significant at the level of 0.01 , while job search guidance and willingness to learn were positively correlated in a lower degree, and their correlation was significant at the 0.05 level, indicating that business administration personnel training modes and students' willingness to learn were positively correlated. Figure 3 shows that $\mathrm{H} 2$ was validated, namely that business administration personnel training modes and students' willingness to learn combined affect students' employability, and the various dimensions of personnel training modes and students' willingness to learn play different roles in predicting the various dimensions of students' employability. 
Practical training and teachers' teaching skills and attitudes have a significantly predictive effect on students' basic skills; curriculum and willingness to learn have a significantly predictive effect on students' specialized competence; training evaluation and job search guidance have a significantly predictive effect on students' ability to outreach; teachers' teaching ability and practical training have a significantly predictive effect on students' capability of career development; practical training and campus culture construction have a significantly predictive effect on students' management capability.

\section{Acknowledgements}

Research project under Ministry of Education Chinese Foundation for Teacher Development: CTF 120862; sub-project: KYH361

\section{References}

[1] Hillage J, Pollard E. Employability: Developing a Framework for Policy Analysis. Research Brief 85, Department for Education and Employment, pp. 4-8. (1998)

[2] Little. Interaational perspective on employability. Enhancing Student Employability CO-ordination Team\& LTSN Generic Centre January. pp. 6. (2003)

[3] Yorke.Employability in Higher Education: What Is or What Is Not. Enhancing Student Employability CO-ordination Team\& LTSN Generic Centre, pp. 7-9. (2004)

[4] Lachance J R The HR Workforce: Meeting the Challenge of Change. United States Office of Personnel Management, Washington, DC, January, pp. 8. (2000)

[5] Zwell M. Creating a Culture of Competence-New York: John Wiley\& Sons Inc. (2000)

[6] Streiner D L, Norman G R. Health Measurement Scales: a Practical Guide to Their Development and Use. Oxford: Oxford University Press, pp. 39-52. (1989)

[7] Li xing. Characteristics influence for Entrepreneurship behavior ability, Advances in social science Education and Humanities Research, Vol. 17, pp. 609-614. (2015) 